\title{
DOSSIER 2. 100 AÑOS DEL CURSO DE LINGÜÍSTICA GENERAL CLG
}

\section{Presentación}

- Unde Exoriar? En los cien años del "Curso de lingüística general" de Ferdinand de Saussure (Miguel Ángel Mahecha)

Unde Exoriar? In the one hundred years of the "Course on General Linguistics" by Ferdinand de Saussure

\section{Textos clásicos}

- Prólogo a la versión española del Curso de lingüística general (Amado Alonso)

Prologue to the Spanish version of the General Linguistics Course

- Proceso de producción de una teoría lingüística y semiológica (Ana María Nethol)

Production process of a linguistic and semiological theory

- Lingüística general de Ferdinand de Saussure. El primer curso. Introducción.

(Claudia Mejía)

General linguistics of Ferdinand de Saussure. The first course. Introduction.

\section{Artículos}

- Le Cours de linguistique générale et l'histoire du saussurisme (Anne-Gaëlle Toutain)

The Course of General Linguistics and the History of Saussurism

- Un bon exercice de lecture du Cours de linguistique générale (Claire A. Forel)

A good reading exercise of the General Linguistics Course

- Les cours de linguistique générale de Ferdinand de Saussure, un projet de Paul-F. Regard et Antoine Meillet (Claudia Mejía)

The courses of general linguistics of Ferdinand de Saussure, a project of Paul-F. Regard and Antoine Meillet

- El Curso de lingüística general de Saussure y su importancia en el desarrollo de la lingüística estructural (Gerda Haßler)

The Course of general linguistics of Saussure and its importance in the development of structural linguistics

- Ontologie et épistémologie de la linguistique dans les textes originaux de Ferdinand de Saussure

(Simon Bouquet)

Ontology and epistemology of linguistics in the original texts of Ferdinand de Saussure

- Some remarks on Chomsky's reading of Saussure (Frederick J. Newmeyer)

Algunas observaciones sobre la lectura chomskyana de Saussure

- Saussure and Chomsky. Langue and I-language (Naoki Araki)

Saussure y Chomsky. Lengua e I-language

- Ferdinand de Saussure y el Curso de lingüística general (Xavier Laborda)

Ferdinand de Saussure and the Course of general linguistics

- Ce que les théories du discours doivent à Saussure (Pierre-Yves Testenoire)

What the theories of speech owe to Saussure 


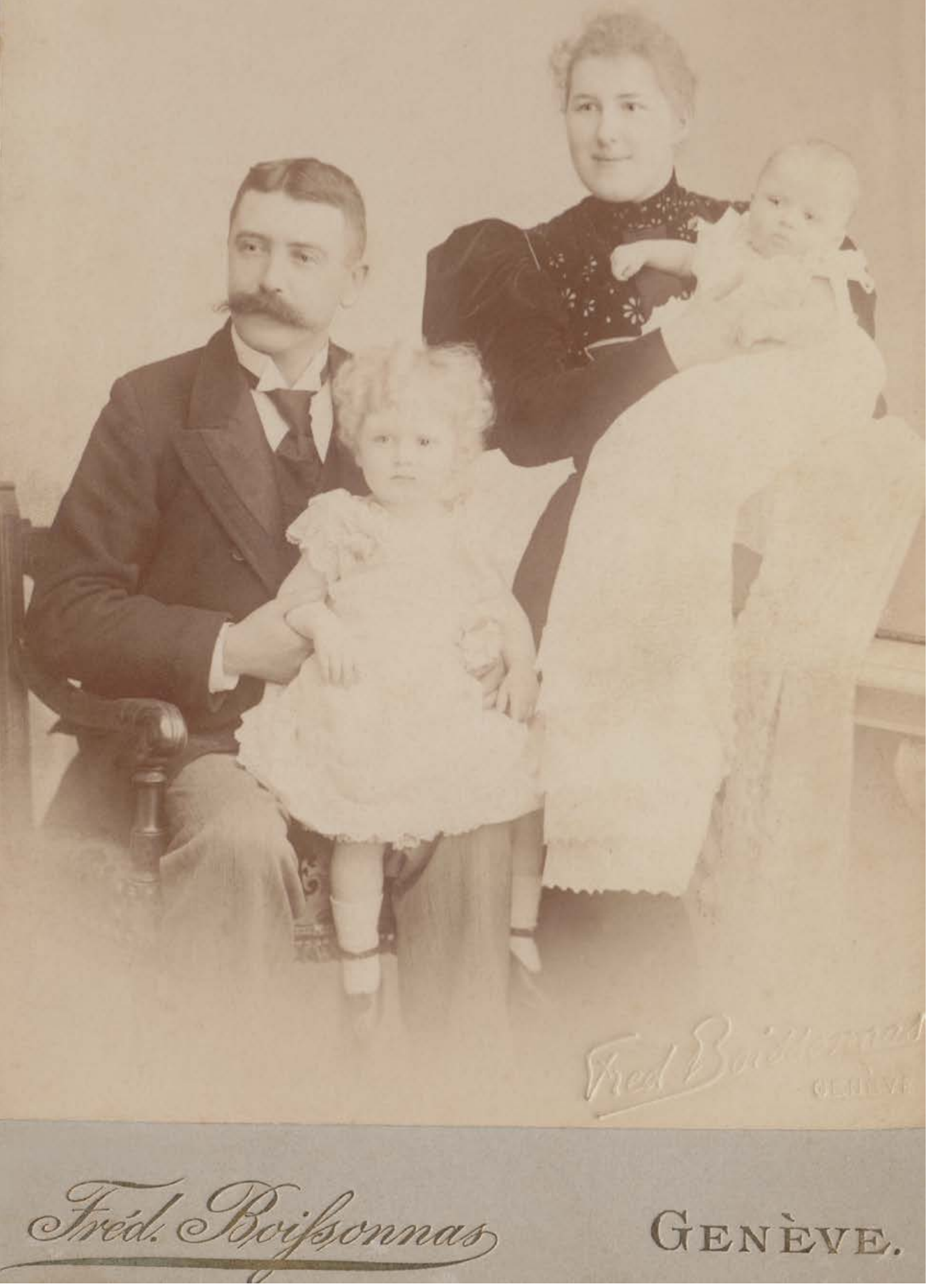

